\title{
The energy union - a new step towards sustainability by promoting clean energy
}

\author{
Ana-Maria Iulia ŞANTA \\ The Bucharest University of Economic Studies; Doctoral School of Business Administration, \\ Bucharest, Romania \\ anamaria_iulia_santa@yahoo.com
}

\begin{abstract}
The Energy Union is an important issue on the agenda of the European Commission, which is addressed in the package "Clean Energy for All Europeans", adopted by the European Commission in November 2016. The present paper deals with the role of the Energy Union in ensuring an optimal framework for a common energy market at the level of the European Union, aimed for the benefit of the consumers in the European Union and of a modern and functional business environment. Which perspectives opens this possible win-win situation is a topic to be analyzed in the present article. The Energy Union is a stronger form of integration within the European Union, related to the internal market of the European Union, which brings more than harmonization of standards and mutual recognition: it brings a common policy and shared values. The goal of this project is to ensure consumer protection through common rules and harmonization, which is a trend at the level of the European Union occurring in various fields of activity and business sectors, such as the Energy Union, the Banking Union, data protection and the competition framework. The main focus on the consumer is new, compared to former attempts of harmonization in specific fields. The challenge rising from this project is to achieve a union in a strategic sector, such as energy. Possible aspects that could hamper the building of the union will be analyzed, for example the fact that some member states of the European Union still rely on fossil fuels, such as the coal industry. The switch to renewable energy sources is related to high costs, as well as to social turbulences on the labour market, that have to be taken into consideration. When drafting measures for the Energy Union, the effects on climate change as well as socio-economic parameters have to be weighed, in order to find the proper balance. It is therefore important to draft appropriate measures ensuring a smooth transition from fossil fuels to Clean Energy. The present paper focuses on these measures proposed by the European Commission. The key elements of the Energy Union will be analyzed in the measures drafted by the European Commission in the package "Clean Energy for All Europeans". Case studies will illustrate the debated aspects and will provide best practice guidelines as a result. An interdisciplinary approach will be used in the present paper, combining economic and legal issues in a comparative manner.
\end{abstract}

Keywords: Energy Union, Sustainability, Clean Energy, Common Energy Market, consumer protection, harmonization.

\section{Introduction}

Promoting Clean Energy is an important goal of the European Union, which is reflected in the "Clean Energy for All Europeans" package of the European Commission, published on the $30^{\text {th }}$ November 2016. Energy efficiency and renewable energy are key elements of this package (European Commission - Press release, Clean Energy for All Europeans - unlocking Europe's growth potential). In order to achieve the goals of this strategy related to climate change and energy policies, the "Clean Energy for All Europeans" package of the European Commission contains a new Renewable Energy Directive, proposals for the electricity market design and for the Energy Union Governance (https://ec.europa.eu/energy/en/ topics/ energy-strategy-and-energy-union/clean-energy-all-europeans). 
The current project of the Energy Union in the European Union is the result of several harmonization attempts in the energy sector. The Energy Union is a stronger form of integration within the European Union, related to the internal market of the European Union, which brings more than harmonization of standards and mutual recognition: it brings a common policy and shared values. Several steps have been performed in the past in order to achieve a harmonized market in the energy sector at the level of the European Union.

A common shared value is the focus on the consumer, which is a core element of the new project of the Energy Union. The focus on the consumer is new, compared to former attempts of harmonization performed in the past. The benefits of the package "Clean Energy for All Europeans" are more convenient energy prices offered to the consumers in the European Union, a better possibility of choice offered to the consumer, as well as more transparency (http://ec.europa.eu/energy/en/news/commission-proposes-new-rulesconsumer-centred-clean-energy-transition). The increased role of the consumer when drafting this project of the Energy Union itself is an advantage.

Moreover, the Energy Union offers growth perspectives for investors, so it offers better development possibilities for the business environment and it contributes as well to job creation, so it is a win-win situation for both consumers and investors in the European Union.

Another important aspect of the Energy Union is sustainability. The package "Clean Energy for All Europeans" contributes to ensuring sustainability by providing energy efficiency and by supporting the modernization of the energy sector by promoting renewable energy. The use of clean energy is important for a sustainable energy policy and for having a clean environment. A clean environment is important for the health of the consumers in the European Union and for offering them better conditions. It brings as well new opportunities for innovation, thus supporting the development of the business environment and of new competitive technologies in the energy sector (http://ec.europa.eu/energy/en/news/commission-proposes-new-rules-consumercentred-clean-energy-transition).

Previous studies, articles and works related to the topic of energy efficiency and of sustainability in the energy sector have been consulted, for example Fremuth and Parak (2002), Sioshansi and Pfaffenberger (2006), Glachant and Lévêque (2009) and Sorrell et al, (2004). The present article is in line with the previous research related to sustainability by promoting energy efficiency and clean energy. Moreover, the present article creates a connection between the previous research and the very new topic of Energy Union, with focus on the consumer, which is a very new project of the European Union. As the Package "Clean Energy for All Europeans" was released in November 2016, the topic is still very new, so there is a research gap in this field. Further research is going to be needed in this field.

The present article aims to debate the following research questions: Is the Energy Union a new step in order to ensure sustainability within the European Union? Which are the advantages of using clean energy? Which concrete measures of the European Commission comprised in the package "Clean Energy for All Europeans" aim to implement the project of the Energy Union as a new step towards sustainability in the European Union? Which role do consumers play in this context? 


\section{Literature review}

The topic of sustainability achieved by the project of the Energy Union is new and very important at the level of the European Union. The package "Clean Energy for All Europeans", adopted on the $30^{\text {th }}$ November 2016, aims to contribute to the modernization of the energy sector and to the improvement of the living conditions of the consumer and of the business environment in the European Union.

PICBE | 898

There have been several steps in order to achieve harmonization in the field of the electricity market within the European Union through the First Package, the Second Package and the Third Package, according to the European Commission (http://ec.europa.eu/energy/sites/ener/files/documents/1_en_autre_document_travail_se rvice_part1_v2.pdf), but there are still aspects to be improved. These improvements could be achieved through the package "Clean Energy for All Europeans", which opens new perspectives to the common European energy market by the establishment of an Energy Union.

It is an interesting finding to figure out that the basic principles of the electricity policy have not changed in the past twenty years. Such principles, which are the basis of the Energy Union, have always been the basic principles of the energy policy in the European Union: the principle of security of supply, the principle of the common market, the principle of transparency and non-discrimination, the principle of environment protection, the principle of economic and social cohesion and employment policy (Briche, 1997, pp. 7-8). These principles established twenty years ago are still valid and build common values within the European Union and thus they are the basis for the new project of the Energy Union.

The present article further develops the results of previous research and correlates them to the actual trends of European Union policy in the energy sector. This analysis represents the contribution of the present article to research.

\section{Research topics and research methodology}

The concept of Energy Union with focus on the consumer and on sustainability is a topic of great interest in the European Union. At the basis of this concept there is a harmonized framework which permits cooperation and a common policy.

The package "Clean Energy for All Europeans" containing a proposal for a Renewable Energy Directive offers the possibility to design a common energy market at the level of the European Union.

In this context it is interesting to analyze how the principle of subsidiarity is implemented in the energy sector and to what extent the Member States have delegated some of their competencies to the European Union. In some policy sectors, for example in the European Competition Policy, the European Union has exclusive competencies. In some other sectors there are shared competencies at the level of the European Union. It is interesting to find out what is the specific situation in the energy sector and how does the cooperation between the Members States of the European Union take place.

The present paper analyzes the interaction between the supranational level of the European Union and the national level of the Member States of the European Union when drafting the common energy policy.

The research questions discussed in the present article are the following: 
- Is the Energy Union a new step in order to ensure sustainability within the European Union?

- Which are the advantages of using clean energy?

- Which concrete measures of the European Commission comprised in the package "Clean Energy for All Europeans" aim to implement the project of the Energy Union as a new step towards sustainability in the European Union?

- Which role do consumers play in this context?

In order to find answers to the research questions of the present article important documents contained in the package "Clean Energy for All Europeans" will be analyzed. A multidisciplinary approach will be used for the research, combining the analysis of legal provisions with the analysis of the economic and social impact of the proposed measures in the package "Clean Energy for All Europeans".

A mix of qualitative methods for the interdisciplinary aspects and of quantitative methods for the analysis of key indicators related to the Energy Union will be used. Some examples of key indicators related to the Energy Union to be analyzed are: net import dependency, Aggregate supplier concentration index, Electricity interconnection, Market concentration index for power generation, Market concentration index for wholesale gas supply, Final energy consumption, Renewable energy share, Public investments on Energy Union related R\&I (\%GDP), patents related to Energy Union R\&I priorities (per inhabitant) (https://ec.europa.eu/commission/sites/beta-political/files/swd-energy-union-keyindicators_en.pdf). The information used is available in the documents provided by the European Commission (e.g. Second Report on the State of the Energy Union, COMMISSION STAFF WORKING DOCUMENT, Monitoring progress towards the Energy Union objectives key indicators, available at https://ec.europa.eu/commission/sites/betapolitical/files/swd-energy-union-key-indicators_en.pdf). The data is provided by Eurostat and by the European Commission.

\section{Discussions}

The Energy Union is a strong form of integration of the energy market, based on a common policy and on common values. But this result has been achieved step by step, by progressive harmonization of the rules and standards in the energy sector. This evolution occurred in time. The first steps towards the harmonization of this sector were performed in the 1990's and were initiated by the European Commission. A next step in the harmonization process was the Directive 96/92/EG related to the electricity market. Further steps in developing a common framework were the "Second Energy Package" from 2003 and "The Third Energy Package" in 2009.

The continuation of this harmonization process is the package "Clean Energy for All Europeans". The documents presented in this package put a strong focus on the consumer and this orientation is a new element in the energy policy. (https://ec.europa.eu/energy/en/news/new-electricity-market-consumers).

Another important element promoted in the package "Clean Energy for All Europeans" is transparency on the market. It is important to ensure transparency, as this is a key aspect for building a functional market (Fremuth and Parak, 2002, p. 166).

A business environment functioning on the principle of non-discrimination is very important. This is why the documents contained in the package "Clean Energy for All 
Europeans" propose a phasing out of discriminatory rules on the energy market (https://ec.europa.eu/energy/en/news/new-electricity-market-consumers). This could have as an effect a better and more efficient use of energy and of the established network (https://ec.europa.eu/energy/en/news/new-electricity-market-consumers).

This is important in order to achieve a further step towards sustainability, which is a goal of the Energy Union. Another focus point of the package "Clean Energy for All Europeans" is the promotion of renewable energy, which contributes to a sustainable and clean environment (https://ec.europa.eu/energy/en/news/new-electricity-marketconsumers).

Defining the concept of Clean Energy is an important task and a first step in order to design the Energy Union. Clean Energy refers to the energy produced from resources with less pollution than the conventional energy, such as the renewable energy (Weber and Page, 2012, p. 2). The renewable energy is wind, solar and geothermal energy, as well as biomass and biogas energy (Weber and Page, 2012, p. 2).

The increasing importance of Clean Energy within the European Union is reflected in the following table, which is presented in Annex 1 of the Annexes to the Proposal for a Directive of the European Parliament and the Council on the promotion of the use of energy from renewable sources (http://eur-lex.europa.eu/legalcontent/EN/TXT/HTML/?uri=CELEX:52016PC0767\&from=EN):

Table 1. National overall targets for the share of energy from renewable sources in gross final consumption of energy in 2020

\begin{tabular}{|c|c|c|}
\hline $\begin{array}{l}\text { Member State } \\
\text { of the } \\
\text { European Union }\end{array}$ & $\begin{array}{l}\text { Share of energy from renewable } \\
\text { sources in gross final consumption } \\
\text { of energy, } 2005\left(S_{2005}\right)\end{array}$ & $\begin{array}{l}\text { Target for share of energy from } \\
\text { renewable sources in gross final } \\
\text { consumption of energy, } 2020\left(S_{2020}\right)\end{array}$ \\
\hline Belgium & $2,2 \%$ & $13 \%$ \\
\hline Bulgaria & $9,4 \%$ & $16 \%$ \\
\hline Germany & $5,8 \%$ & $18 \%$ \\
\hline Spain & $8,7 \%$ & $20 \%$ \\
\hline France & $10,3 \%$ & $23 \%$ \\
\hline Italy & $5,2 \%$ & $17 \%$ \\
\hline Luxembourg & $0,9 \%$ & $11 \%$ \\
\hline Netherlands & $2,4 \%$ & $14 \%$ \\
\hline Austria & $23,3 \%$ & $34 \%$ \\
\hline Poland & $7,2 \%$ & $15 \%$ \\
\hline Portugal & $20,5 \%$ & $31 \%$ \\
\hline Romania & $17,8 \%$ & $24 \%$ \\
\hline
\end{tabular}

Source: Annex 1 of the Annexes to the Proposal for a Directive of the European Parliament and the Council on the promotion of the use of energy from renewable sources (http://eur-lex.europa.eu/legalcontent/EN/TXT/HTML/?uri=CELEX:52016PC0767\&from=EN).

Another important concept related to the subject of clean energy is energy efficiency. Energy efficiency aims to use less energy in order to provide the same level or a better level of services to the consumer by using an economic efficient way (Weber and Page, 2012, p. 2).

Innovation based technologies are important in order to achieve energy efficiency (Weber and Page, 2012, p. 2). In this context entrepreneurship plays a very important role, as it identifies market opportunities for clean energy technologies, it promotes the 
improvement of these technologies and it creates viable business models for the clean energy sector (Malen and Marcus, 2017, pp. 7-15).

Another important aspect to be discussed related to the topic of the Energy Union and of Clean Energy is interconnection. The enforced cooperation and the design of the Energy Union are important for building a common market, where interconnection is possible. This element is important for granting a sustainable and fair business environment (Glachant and Lévêque, 2009).

European institutions play a major role in ensuring a harmonized framework of a sustainable energy sector and in promoting the Energy Union. The European Commission initiated the steps towards harmonization of this sector twenty years ago and it still is nowadays the European institution with important competencies and with a very important role in drafting the proposed measures of the package "Clean Energy for All Europeans". Two important legislative proposals to be discussed related to this package are the following: proposal for a Directive of the European Parliament and of the Council amending Directive 2012/27/EU on energy efficiency (COM(2016)0761 - C8-0498/2016 2016/0376(COD)) and proposal for a Directive of the European Parliament and of the Council on the promotion of the use of energy from renewable sources (recast) (COM(2016)0767 - C8-0500/2016 - 2016/0382(COD)). These proposals were recently discussed in the Committee on Industry, Research and Energy of the European Parliament.

The proposal for a Directive of the European Parliament and of the Council amending Directive 2012/27/EU on energy efficiency (COM(2016)0761 - C8-0498/2016 2016/0376(COD) highlights the importance of energy efficiency for ensuring the reduction of greenhouse gas emissions, for ensuring energy security, for reducing the effects of energy poverty and for generating economic development within the European Union. Investments are important in order to improve energy efficiency. At the same time, it is important to assess the capacities of each Member State of the European Union in providing renewable energy, in order to avoid disturbances. The proposal underlines as well the importance of the interconnection of national energy systems, in order to ensure an efficient energy mix for all Member States of the European Union (Proposal for a Directive of the European Parliament and of the Council amending Directive 2012/27/EU on energy efficiency). The proposal for a Directive of the European Parliament and of the Council amending Directive $2012 / 27 / \mathrm{EU}$ on energy efficiency underlines the important role of the consumer as a key player in the energy sector and in the design of the policies of this sector. The proposal has as well a strong economic dimension by the fact that energy efficiency contributes to economic growth, to better job opportunities created by the modernization of the energy sector and to the support of a competitive and dynamic business environment in this strategic field. Moreover, the proposal for a Directive of the European Parliament and of the Council amending Directive 2012/27/EU on energy efficiency has as well a social dimension, by the fact that it takes energy poverty into consideration, as well as the vulnerable consumers that must be protected by ensuring energy bills with decreasing amounts(http://eur-lex.europa.eu/legalcontent/EN/TXT/?qid=1485938766830\&uri=CEL EX :52016PC0761). The proposal for a Directive of the European Parliament and of the Council amending Directive 2012/27/EU on energy efficiency is in line with other policy provisions, for example with the new Governance regulation, with the new electricity market design and the legislation in the field of renewable energy. It is important to discuss the principle of subsidiarity in this context, as the energy sector is a strategic sector and it is 
a difficult task to establish which competencies the Member States are willing to delegate to the supranational level of European institutions in charge with drafting the policy of the Energy Union and which competencies they will keep at national level. Given the fact that there are disparities between the national energy markets of the Member States within the European Union, some actions related to the field of energy efficiency are better performed at the level of the European Union, which offers support to the Member States. The principle of subsidiarity is respected and Member States have a certain degree of flexibility in establishing the energy mix that suits best for their market (http://eurlex.europa.eu/legal-content/EN/TXT/?qid=1485938766830\&uri= CELEX:52016PC0761).

The proposal for a Directive of the European Parliament and of the Council on the promotion of the use of energy from renewable sources (recast) (COM(2016)0767 C8-0500/2016 - 2016/0382(COD)) underlines the fact that promoting energy from renewable sources is together with energy efficiency part of the policy for reducing greenhouse gas emissions and of compliance with the Paris Agreement on Climate Change from 2015 and the Union 2030 Energy and Climate framework. The proposal highlights the importance of renewable energy in ensuring employment and regional development. Investments in renewable energy should be facilitated in the Member States of the European Union and financial instruments should be provided in order to reach this goal (Proposal for a Directive of the European Parliament and of the Council on the promotion of the use of energy from renewable sources). The proposal for a Directive of the European Parliament and of the Council on the promotion of the use of energy from renewable sources is in line with other existing policy provisions, namely with the proposals related to Energy Union Governance and to Market Design. This proposal regarding the use of energy from renewable sources has a complimentary function to the proposals of Market Design, by aiming to create an optimal framework for investments in this sector, that will bring benefits to the consumer but as well to the entrepreneurs and the investors in this field (http://eur-lex.europa.eu/legalcontent/EN/TXT/?uri=CELEX:52016PC0767R\%2801\%29). The principle of subsidiarity plays a very important role in the context of the proposal for a Directive of the European Parliament and of the Council on the promotion of the use of energy from renewable sources, as the European Union does not have exclusive competencies in the field of renewable energies.

The analysis of the above-mentioned documents demonstrates that this field is one with a high degree of interdisciplinarity, combining legal aspects with economic, social and political dimensions. The interconnections between these aspects are strong, they must be taken into consideration and they influence the complex measures that have to be drafted.

The social impact of the package "Clean Energy for All Europeans" has to be analyzed by taking into account the positive aspects and as well the negative aspects or the challenges of this project at social level. The positive aspects related to this project are the sustainability, the more convenient energy prices, the clean environment and the better living conditions for the consumers within the European Union, which are advantages of this project, reflected in our society. The respect towards the environment and raising of awareness in this field are factors with social impact. Another positive element related to this package is the social cohesion aimed by this project, which would ensure better and healthier living conditions for all the consumers within the European Union, with no disparities between the Member States of the European Union (Briche, 1997, pp. 7-8). The fact that energy poverty and vulnerable consumers are taken into consideration when 
drafting measures of the package "Clean Energy for All Europeans" has a social dimension. Other positive effects at social level are reflected in the employment policy by job creation in the field of clean energy (Briche, 1997, pp. 7-8). Besides new jobs in the field of green energy, new trends for investments in clean energy will as well develop. The package "Clean Energy for All Europeans" is a common project with shared values at the level of the European Union, which will contribute to a stronger European Union, relying on unity and solidarity in its views and in its policies, as well as on consumer respect and consumer focus.

On the other hand, the package "Clean Energy for All Europeans" is as well related to some challenges at social level, like the disparities between national energy markets of the Member States of the European Union. The harmonization attempts for achieving a common energy policy at the level of the European Union might cause disturbances on the labour market of some Member States and divergent opinions of these Member States on European projects. This is the case of Poland, for instance, which is still relying on its coal industry for generating energy and on its mining sector. Promoting clean energy would mean to close mines, so that some jobs in this sector would disappear. The social impact of such a measure could be negative, as it would generate loss of jobs, unemployment, social uncertainty and an insecure future for persons working in the mining sector and in in the coal industry. This is why Poland does not share the same enthusiastic attitude as the European Commission when approaching the issue of promoting green energy.

The increasing importance of clean energy is reflected as in the research activities of the European Commission and on the analysis of relevant quantitative indicators. According to the Second Report on the State of the Energy Union - COMMISSION STAFF WORKING DOCUMENT - Monitoring progress towards the Energy Union objectives - key indicators, the European Commission performs the monitoring of the progress of the Energy Union by using the quantitative indicators mentioned in the table below:

Table 2: Indicators for monitoring progress towards Energy Union objectives

\begin{tabular}{|l|l|}
\hline \multicolumn{1}{|c|}{ Energy Union dimension } \\
$\begin{array}{l}\text { Energy security, solidarity and } \\
\text { trust }\end{array}$ & SoS1: Net import dependence \\
\hline & SoS2: Aggregate supplier concentration index \\
\hline $\begin{array}{l}\text { A fully integrated internal energy } \\
\text { market }\end{array}$ & SoS3: N-1 rule for gas infrastructure \\
\hline & IM1: Electricity interconnection capacity \\
\hline & IM2: Market concentration index for power generation \\
\hline & IM3: Market concentration index for wholesale gas supply \\
\hline & IM4: Wholesale electricity prices \\
\hline & IM5: Wholesale gas prices \\
\hline & IM6: Annual switching rates electricity (household customers) \\
\hline & IM7: Annual switching rates - gas (household customers) \\
\hline $\begin{array}{l}\text { Energy efficiency and moderation in final } \\
\text { of demand }\end{array}$ & $\begin{array}{l}\text { IM8: Energy affordability - energy expenditure share in } \\
\text { consumption expenditure for the lowest quintile }\end{array}$ \\
\hline & EE1: Primary energy consumption \\
\hline & $\begin{array}{l}\text { EE2: Final energy consumption Final energy consumption of main } \\
\text { economic sectors, i }\end{array}$ \\
\hline & EE3: Final energy intensity in industry \\
\hline & EE4: Final energy consumption per square meter in residential sector, \\
\hline
\end{tabular}

DOI: 10.2478/picbe-2018-0080, pp. 896-906, ISSN 2558-9652| Proceedings of the $12^{\text {th }}$ International Conference on Business Excellence 2018 


\begin{tabular}{|l|l|}
\hline & climate corrected \\
\hline & EE5: Final energy consumption in transport \\
\hline & EE6: Final energy intensity in services sector \\
\hline Decarbonisation of economy & DE1: GHG emissions reductions (base year=1990) \\
\hline & $\begin{array}{l}\text { DE2: Gap between GHG emissions projections and 2020 target in } \\
\text { Effort Sharing sectors }\end{array}$ \\
\hline & $\begin{array}{l}\text { DE3: Gap between latest (proxy) inventory of Effort Sharing emissions } \\
\text { and interim targets }\end{array}$ \\
\hline & DE4: GHG intensity \\
\hline $\begin{array}{l}\text { Research, innovation and } \\
\text { competitiveness }\end{array}$ & $\begin{array}{l}\text { RE5: Renewable energy share } \\
\text { Public }\end{array}$ \\
\hline & RIC2: patents related to Energy Union R\&I priorities (per inhabitant) \\
\hline & RIC3: Real unit energy costs in the manufacturing sector (excl. refining \\
\hline
\end{tabular}

Source: European Commission: Second Report on the State of the Energy Union - COMMISSION STAFF WORKING DOCUMENT - Monitoring progress towards the Energy Union objectives - key indicators (https://ec.europa.eu/commission/sites/beta-political/files/swd-energy-union-key-indicators_en.pdf).

The use of these indicators, their meaning and their relevance are explained in the Second Report on the State of the Energy Union - COMMISSION STAFF WORKING DOCUMENT - Monitoring progress towards the Energy Union objectives - key indicators of the European Commission.

\section{Results}

A new legislative framework is currently designed at the level of the European Union in order to support the Energy Union and sustainability through clean energy. The results would be a more efficient use of the energy resources, better living conditions and a healthier environment for the consumers within the European Union, better prices for the consumers, job creation and a modernized business environment in the energy sector, which would promote innovation in clean energy technologies and new business models in the energy sector. Consumers and investors would both benefit from this situation, so it would be a win-win situation. A transparent, non-discriminatory market is needed in order to achieve the Energy Union (Glachant and Lévêque, 2009, p. 85).

A better level of interconnection (Mastropietro et al, 2015) would reduce the market fragmentation in the European Union (Glachant and Lévêque, 2009) and would therefore contribute to the achievement of the Energy Union. An institutional framework allowing this kind of cooperation is designed in the package "Clean Energy for All Europeans", which foresees an Agency for the Cooperation of Energy Regulators (ACER) (http://ec.europa.eu/energy/sites/ener/files/documents/1_en_autre_document_travail_s service_part1_v2.pdf).

This step of an Energy Union allowing more sustainability by clean energy is a further step of market integration, after significant efforts that have been made in the past twenty years in order to achieve harmonization in the energy sector.

\section{Conclusion}

Clean energy is a very important topic on the current agenda of the European institutions. It is a new, developing field, where there is a research gap. The present paper brings a contribution to the analysis of the recent projects and legislative proposals of the European 
Commission regarding the package "Clean Energy for All Europeans". This package is focused on the consumer, but as well on the improvement of the business environment for the benefit of the consumer. The energy sector is dynamic and the importance of clean energy will increase in the context of energy poverty and of the limited resources, so that further research will be necessary.

The topic is of great importance. The harmonization achieved step by step in the past twenty years leads to the possibility to build an Energy Union, with a common policy in this sector. In this context interconnection is an important issue, as well as cooperation, that should be ensured by a common legislative and institutional framework.

These results of the present paper might be further developed and used for future research that will for sure be needed, as the field is gaining an increasing importance at the level of the European Union and it will further extend in the future.

\section{Bibliography}

Briche, Brigitte (1997). Die Elektrizitätswirtschaft in der Europäischen Union: Institutionelle und materielle Aspekte, Schriften des Europa-Instituts des Saarlandes - Rechtswissenschaft, Band 15, 1. Auflage, Baden-Baden: Nomos Verlagsgesellschaft.

Eur-Lex (official website) retrieved from URLhttp://eur-lex.europa.eu/legalcontent/EN/TXT/?qid=1485938766830\&uri=CELEX:52016PC0761 [accessed on 12.01.2018].

Eur-Lex (official website) retrieved from URLhttp://eur-lex.europa.eu/legalcontent/EN/TXT/?uri=CELEX:52016PC0767R\%2801\%29 [accessed on 12.01.2018].

Eur-Lex (official website) retrieved from URLhttp://eur-lex.europa.eu/legalcontent/EN/TXT/HTML/?uri=CELEX:52016PC0767\&from=EN [accessed on 18.02.2018].

European Commission - Press release, Clean Energy for All Europeans - unlocking Europe's growth potential retrieved from URL http://europa.eu/rapid/press-release_IP-164009_en.htm [accessed on 24.12.2017].

European Commission (official website) retrieved from URL https://ec.europa.eu/energy/en/topics/energy-strategy-and-energy-union/cleanenergy-all-europeans [accessed on 29.12.2017].

European Commission (official website) retrieved from URL http://ec.europa.eu/energy/en/news/commission-proposes-new-rules-consumercentred-clean-energy-transition [accessed on 29.12.2017].

European Commission (official website) retrieved from URL

http://ec.europa.eu/energy/sites/ener/files/documents/1_en_autre_document_travail_ser vice_part1_v2.pdf [accessed on 29.12.2017].

European Commission (official website) retrieved from URL https://ec.europa.eu/commission/sites/beta-political/files/swd-energy-union-keyindicators_en.pdf [accessed on 30.12.2017].

European Parliament (official website) retrieved from URL http://www.europarl.europa.eu/committees/en/itre/draft-reports.html?action=1 [accessed on 12.01.2018].

Fremuth, Walter \& Parak, Christoph (2002). Regulierung der Deregulierung von Infrastrukturmärkten. Wien: Manzsche Verlags- und Universitätsbuchhandlung. 
Glachant, Jean-Michel \& Lévêque, François (2009). Electricity reform in Europe - Towards a Single Energy Market. Cheltenham, UK, Northhampton, MA, USA: Edward Elgar Publishing Limited.

Littlechild, Stephen (2016). The CMA energy market investigation, the well-functioning market, Ofgem, Government and behavioural economics. European competition journal [1744-1056], pp. 1 -63.

PICBE | 906

Malen, Joel \& Marcus, Alfred A. (2017). Promoting clean energy technology entrepreneurship: The role of external context, Energy Policy, March 2017, 102, 715.

Mastropietro, Paolo, Rodilla, Pablo, Batlle, Carlos (2015). National capacity mechanisms in the European internal energy market: Opening the doors to neighbours. Energy policy, 82, $38-47$.

Sorrell, Steve, O'Maley, Eoin, Schleich, Joachim \& Scott, Sue (2004). The Economics of Energy Efficiency. Cheltenham, UK, Northhampton, MA, USA: Edward Elgar Publishing Limited.

Sioshansi, Fereidoon, P. \& Pfaffenberger, Wolfgang (2006). Electricity market reform - an international perspective. Oxford: Elsevier.

Weber, A., \& Page, G. T. (2012). Clean Energy: Benefits and Lessons for States. New York: Nova Science Publishers, Inc. 